\title{
Dynamiek in overscholing en verdringing op de arbeidsmarkt ${ }^{*}$
}

\author{
Maarten H.J. Wolbers ${ }^{* *}$
}

In dit artikel staat de dynamiek in overscholing en verdringing op de Nederlandse arbeidsmarkt centraal. Meer specifiek wordt nagegaan in hoeverre deze overscholing en verdringing van structurele of cyclische aard is. Daartoe worden ontwikkelingen in de overgangskans van passend werk naar overscholing, werkloosheid of inactiviteit en andersom geanalyseerd. Resultaten van discrete-tijd gebeurtenissenanalyse, uitgevoerd op het OSA Arbeidsaanbodpanel 1988-2004, laten zien dat er sprake is van cyclische overscholing en verdringing. Allereerst is aangetoond dat de overgangskans van passend werk naar overscholing, werkloosheid of inactiviteit groter is, naarmate het werkloosheidspeil hoger is. Daarnaast hebben de bevindingen laten zien dat de kans op passend werk vanuit een toestand van overscholing, werkloosheid of inactiviteit kleiner is, wanneer de werkloosheid hoger is. Er is geen steun gevonden voor structurele overscholing en verdringing op de Nederlandse arbeidsmarkt.

\section{Inleiding}

Uit eerder onderzoek is gebleken dat de positie van lager opgeleide werknemers op de Nederlandse arbeidsmarkt de afgelopen decennia is verslechterd (zie bijvoorbeeld Gesthuizen, 2008). Daarvoor worden ten minste twee verklaringen geopperd. Een eerste verklaring luidt dat technologische ontwikkelingen, en meer specifiek het toegenomen gebruik van computers op de werkplek, hebben geleid tot een verschuiving in de vraag van laag- naar hooggeschoolde arbeid. Hierdoor zouden de arbeidsmarktkansen van lager opgeleiden zijn verslechterd (Levy \& Murnane, 1992; Krueger, 1993). Ongetwijfeld heeft deze opwaardering van de beroepenstructuur plaatsgevonden. Het aandeel elementaire beroepen in de totale beroepenstructuur in Nederland is echter behoorlijk constant gebleven, en is mogelijk zelfs licht gestegen sinds de jaren zeventig van de vorige eeuw (De Beer, 2006; Salverda et al., 2008). De overgang van een economie gedomineerd door traditionele industrie naar een diensteneconomie heeft veel ongeschoold werk overbodig gemaakt; vooral in de industrie. Tegelijkertijd zijn er echter veel ongeschoolde banen bijgekomen in de dienstensector (vooral in de horeca en de schoonmaakbranche), omdat bedrijven dit werk veelal uitbesteden. Het is daarom

* De inleiding en theoretische achtergrond van dit artikel zijn grotendeels ontleend aan Gesthuizen en Wolbers (2010). De auteur bedankt Maurice Gesthuizen voor zijn commentaar op een eerdere versie van dit artikel.

** Maarten H.J. Wolbers is werkzaam bij de sectie Sociologie, Radboud Universiteit Nijmegen, Postbus 9104, 6500 HE Nijmegen. E-mail: m.wolbers@maw.ru.nl. Website: www.socsci.ru.nl/ $\sim$ maartenw. 
onwaarschijnlijk dat de opwaardering van de beroepsarbeid de drijvende kracht is geweest achter de verslechterde arbeidsmarktkansen van lager opgeleiden in Nederland.

Een tweede gangbare verklaring is overscholing en verdringing op de arbeidsmarkt. In dit proces bezetten hoger geschoolde werknemers, omdat ze geen passend werk op hun eigen niveau kunnen vinden, in toenemende mate banen die eerder werden uitgeoefend door middelbaar geschoolden, die vervolgens weer in banen terechtkomen die voorheen door lager opgeleiden werden bezet (het zogenoemde cascade-effect). De uiterste consequentie van deze neerwaartse verdringing is dat werknemers aan de onderkant van de arbeidsmarkt een relatief groot risico lopen op werkloosheid of inactiviteit. De arbeidsmarktkansen van lager opgeleiden kunnen dus verslechteren ondanks het feit dat het aandeel laaggeschoold werk over de tijd heen niet afneemt. Twee bevindingen ondersteunen de verdringingshypothese voor Nederland. In de eerste plaats is het gemiddelde niveau van vereiste vaardigheden op de arbeidsmarkt minder snel toegenomen dan het gemiddelde opleidingsniveau van de Nederlandse beroepsbevolking. Door beide trends te indexeren $(1977=100)$ vonden Batenburg en De Witte (2001) een gemiddeld vaardigheidsniveau van beroepen van 113 in 1995, terwijl het opleidingsniveau van werknemers was gestegen naar 134 in hetzelfde jaar. Vooral het aandeel tertiair gekwalificeerden in de werkzame beroepsbevolking nam sterk toe in deze periode (van 12 naar 26 procent). In de tweede plaats - en samenhangend met het eerste punt - is het aandeel overgeschoolde werknemers in laaggeschoolde banen gestegen. In het begin van de jaren zeventig van de vorige eeuw werden praktisch alle laaggeschoolde banen bezet door lager opgeleide werknemers, terwijl in het midden van de jaren negentig 40 procent van deze banen werden bezet door werknemers met een middelbaar of hoog opleidingsniveau (De Beer, 2006). Waarschijnlijk is dit percentage de afgelopen jaren nog verder gestegen. ${ }^{1}$

Het overgrote deel van het sociologische onderzoek naar overscholing en verdringing op de Nederlandse arbeidsmarkt richt zich op langetermijnontwikkelingen in de opbrengsten van diploma's (zie bijvoorbeeld Wolbers \& De Graaf, 1996). Hierin wordt een structurele verklaring gebruikt. Als de onderwijsexpansie niet kan worden opgevangen door een overeenkomstige opwaardering van de beroepsarbeid, dan zullen hoger opgeleiden, die geen toegang meer hebben tot de beste posities op de arbeidsmarkt, hun heil gaan zoeken in banen onder hun niveau, met de hierboven beschreven verdringing van lager opgeleiden als gevolg.

In de economische literatuur houden de meeste studies over overscholing en verdringing in Nederland zich daarentegen bezig met de invloed van de conjunctuur (Teulings \& Koopmanschap, 1989; Van Ours \& Ridder, 1995; Gautier et al., 2002). De heersende consensus lijkt dat de arbeidsmarktkansen van lager opgeleiden vooral verslechteren onder ongunstige economische omstandigheden, maar dat de afstand tot hoger geschoolden hersteld wordt tot het voorgaande niveau wanneer de economische wind weer gunstig waait. Het achterliggende argument is dat hooggeschoolde werknemers slechts tijdelijk een baan onder hun niveau accepteren (in plaats van werkloos te blijven) en door blijven zoeken naar beter passend werk. Wanneer zij dit vinden - en deze kans is groter naarmate de 
macro-economische omstandigheden gunstiger zijn - verdringen zij lager opgeleiden niet langer, en nemen vervolgens ook de arbeidsmarktkansen van de laatstgenoemden weer toe.

In dit artikel onderzoeken we overscholing en verdringing op de Nederlandse arbeidsmarkt tussen 1990 en 2004. Daartoe bestuderen we op basis van het OSA Arbeidsaanbodpanel de overgang van passend werk naar overscholing, werkloosheid of inactiviteit (beide laatste als indicatoren voor verdringing) en andersom. Daarmee kunnen we de dynamiek in overscholing en verdringing blootleggen. Het gaat er dus niet om veranderingen in de mate van overscholing en verdringing op de Nederlandse arbeidsmarkt te duiden, maar vast te stellen hoe de individuele kans om overgeschoold of verdrongen te worden en te blijven zich heeft ontwikkeld in de loop van de tijd. Vervolgens gaan we na hoe deze dynamiek in overscholing en verdringing kan worden verklaard. Ligt er een structurele dan wel cyclische oorzaak aan ten grondslag?

\section{Theoretische achtergrond}

In het onderzoek naar sociale stratificatie en mobiliteit wordt de moderniseringstheorie veelvuldig gebruikt (Blau \& Duncan, 1967; Treiman, 1970). Deze theorie stelt dat moderne samenlevingen worden gekenmerkt door een efficiënte selectie en allocatie op de arbeidsmarkt die niet langer plaatsvinden op basis van toegeschreven ('ascribed') kenmerken zoals sociale herkomst. In plaats daarvan is het bereiken van een beroepspositie in toenemende mate gebaseerd op verworven ('achieved') kenmerken, met name opgedane kennis en vaardigheden in het onderwijs. Opleidingsniveau wordt daarvoor vaak als maatstaf gebruikt. Empirische steun voor de trend in statusverwerving (van 'ascription' naar 'achievement') voor Nederland is gevonden door De Graaf en Luijkx (1992).

De verklaring voor deze trend is gelegen in technologische ontwikkelingen op de arbeidsmarkt die hebben geleid tot een verschuiving in de vraag van laag- naar hooggeschoolde arbeid (Kerr et al., 1960; Bell, 1974). Deze opwaardering van de beroepsarbeid staat bekend als 'skill biased technological change' (Levy \& Murnane, 1992; Krueger, 1993). In het bijzonder de mechanisering en automatisering van het arbeidsproces hebben geleid tot een verschuiving in de beroepenstructuur, en belangrijker nog, in toegenomen opleidingsvereisten op de arbeidsmarkt. Enerzijds zijn verschillende, laaggekwalificeerde beroepen verdwenen vanwege het feit dat voor veel simpel en ongeschoold werk arbeid is vervangen door machines en computertechnologie. Anderzijds zijn nieuwe, hooggekwalificeerde beroepen ontstaan, met name in de informatietechnologiesector. Tevens zijn de opleidingsvereisten van bestaande beroepen toegenomen. Denk bijvoorbeeld aan het beroep van secretaresse, die gewend was om met een typemachine te werken, maar tegenwoordig overweg moet kunnen met een computer (niet alleen om het toetsenbord te kunnen bedienen, maar ook om de software te kunnen gebruiken). Al met al hebben technologische ontwikkelingen op de arbeidsmarkt dus geleid tot geringe baankansen voor lager opgeleiden en een verslechtering van hun arbeidsmarktpositie. 
Om op microniveau de relatie tussen economische modernisering en de trend van 'ascription' naar 'achievement' te begrijpen, is de 'human capital'-theorie zeer geschikt. Volgens deze theorie vertegenwoordigen de vaardigheden verkregen in het onderwijs menselijk kapitaal (Becker, 1964). Het investeren in menselijk kapitaal is zinvol, zolang als dit leidt tot een hogere productiviteit op de arbeidsmarkt. Werkgevers waarderen arbeidsproductiviteit door de beste banen (vooral in termen van beloning) te bieden aan degenen, die over het meeste menselijk kapitaal (dat wil zeggen, het hoogste opleidingsniveau) beschikken. Dus wanneer technologische ontwikkelingen leiden tot een groei in de vraag naar hooggeschoolde arbeid bij werkgevers, dan investeren (potentiële) werknemers in toenemende mate in opleidingskwalificaties. Als gevolg daarvan heeft de economische modernisering geresulteerd in een enorme toename van de deelname aan het onderwijs. Daarnaast zijn hervormingen bedoeld om het onderwijs meer meritocratisch te maken, relevant geweest. Met name de gereduceerde (directe en indirecte) kosten van het volgen van onderwijs en het verhogen van de leerplichtige leeftijd hebben de onderwijsexpansie verder aangewakkerd.

De vraag is vervolgens of de toegenomen vraag naar hooggeschoolde arbeid gelijke tred houdt met de onderwijsexpansie (Berg, 1971; Livingstone, 1998). Als de opwaardering van de beroepsarbeid de onderwijsexpansie niet kan compenseren, dan zullen de opbrengsten van diploma's op de arbeidsmarkt dalen (ook wel aangeduid als diploma-inflatie) (Wolbers et al., 2001). Het opleidingspeil van opeenvolgende cohorten van schoolverlaters is gestaag gegroeid, hen daarbij in toenemende mate kwalificerend voor hooggeschoolde banen, zonder dat de arbeidsmarkt in staat is geweest dit gestegen aanbod van hoogopgeleiden op te vangen. Daarom moet een toenemend aantal hooggeschoolden een baan onder hun niveau accepteren (dat wil zeggen, een baan aanvaarden waarvoor zij zijn overgeschoold), waardoor zij lager opgeleiden verdringen in nog lagere banen, met als uiterste gevolg dat de laagst opgeleiden werkloos of inactief raken (Borghans \& De Grip, 2000).

Dit proces van neerwaartse verdringing valt te begrijpen vanuit de 'job queue'theorie (Thurow, 1975). Volgens deze theorie zoeken werkgevers de beste kandidaat voor hun vacature tegen de laagste trainingskosten. Ze gebruiken opleidingsniveau daarbij als een indicatie voor trainbaarheid (Spence, 1974). Hiertoe rangschikken werkgevers werkzoekenden in een denkbeeldige wachtrij (op basis van hun verwachte trainingskosten) en koppelen zij deze rij van sollicitanten vervolgens aan een rij met vacante banen, die gerangschikt zijn naar niveau. De beste banen gaan naar degenen met de laagste trainingskosten (dat wil zeggen, de hoogste kwalificaties) en opleiding wordt beschouwd als een positioneel goed (Hirsch, 1977; Ultee, 1980). Er wordt verondersteld dat wanneer een discrepantie bestaat tussen de opwaardering van de beroepsarbeid en de onderwijsexpansie (dat wil zeggen, wanneer er een overaanbod van hoogopgeleiden is), dan een aantal werkzoekenden niet langer de toegang krijgt tot de beste posities en vervolgens een baan tracht te vinden verderop in de wachtrij. Hoger opgeleiden wedijveren in dit geval met lager opgeleiden om posities die voorheen werden bezet door laatstgenoemden. Deze baancompetitie eindigt in succes voor de hoger opgeleiden. Zij hebben immers betere kwalificaties. De uiteindelijke consequentie van dit 
proces is dat individuen, die achteraan in de wachtrij staan, het grootste risico op werkloosheid of inactiviteit lopen.

Deze redenering suggereert dat verdringing als een alternatieve verklaring kan worden beschouwd voor het verminderde arbeidsmarktperspectief voor lager opgeleiden. Niet alleen de verschuiving in de vraag van laag- naar hooggeschoolde arbeid heeft de arbeidsmarktpositie van lager opgeleiden doen verslechteren, maar hun arbeidsmarktkansen zijn bovendien verminderd vanwege het feit dat zij steeds meer uit hun banen worden verdrongen door hoger opgeleiden. Met andere woorden: het probleem is niet dat er te weinig banen aan de onderkant van de arbeidsmarkt zijn, maar juist aan de bovenkant, gezien de enorme onderwijsexpansie die is opgetreden. Het overaanbod van hoger opgeleiden veroorzaakt dat velen van hen een baan onder hun niveau moeten accepteren, daarmee overgeschoold zijn voor hun takenpakket, en tegelijkertijd de kansen op werk voor lager opgeleiden reduceren.

De kwestie is vervolgens of de waargenomen overscholing en verdringing puur structureel zijn, zoals de 'job queue'-theorie voorspelt, dan wel dat zij ook cyclisch van aard zijn (Pollman-Schult, 2005). Het meeste sociologische onderzoek dat betrekking heeft op overscholing en verdringing onderschrijft de structurele verklaring van de 'job queue'-theorie en richt zich op langetermijnontwikkelingen in de opbrengsten van diploma's op de arbeidsmarkt (zie voor Nederland bijvoorbeeld Van der Ploeg (1994) en Wolbers en De Graaf (1996)). De algemene conclusie is dat de opbrengsten van diploma's zijn gedaald in de loop van de tijd, omdat de opwaardering van de beroepsarbeid de enorme onderwijsexpansie niet heeft kunnen bijbenen. Daarom wordt geconcludeerd dat er sprake is van een hardnekkige overinvestering in onderwijs door individuen, met overscholing en verdringing als structureel gevolg.

Onder arbeidseconomen wordt deze conclusie echter sterk in twijfel getrokken (Burris, 2005). Zij beargumenteren dat de statische kijk die sociologen hebben op de arbeidsmarkt weinig recht doet aan haar veronderstelde dynamiek. Economen beweren dat de arbeidsmarkt flexibel genoeg is tijdelijke onevenwichtigheden in vraag en aanbod op te vangen, alhoewel misschien niet zo volledig als wordt voorspeld door de 'human capital'-theorie (bijvoorbeeld vanwege het bestaan van minimumlonen). Om die reden verwijzen zij vaak naar de 'job matching'-theorie (Sattinger, 1993), die als een combinatie van beide eerder genoemde arbeidsmarkttheorieën kan worden beschouwd. Deze theorie stelt dat de kwaliteit van een 'job match', ofwel de mate waarin het vereiste niveau van vaardigheden in een baan overeenkomt met het verworven niveau van vaardigheden in het onderwijs, bepalend is voor het productiviteitsniveau en de beloning in een baan. Als een werknemer is overgeschoold, dan worden zijn verworven vaardigheden on(der)benut. Dit betekent dat de arbeidsproductiviteit beperkt is, hetgeen leidt tot een lager salaris. Empirisch onderzoek toont dit aan (Hartog, 2000). Individuen die werkzaam zijn in een baan waarvoor een lager opleidingsniveau is vereist dan zij feitelijk hebben behaald (dat wil zeggen, overgeschoolde werknemers), verdienen minder dan individuen met een bij het behaalde opleidingsniveau passende baan. Met andere woorden: overscholing rendeert op de arbeidsmarkt, maar minder dan vereiste scholing. 
Vooral in tijden van economische neergang verlagen hoger opgeleiden hun reserveringsloon en accepteren zij een baan onder hun niveau in plaats van werkloos te zijn. Dit leidt weliswaar tot overscholing onder hoger opgeleiden en verdringing onder lager opgeleiden, maar overeenkomstig de 'job search'-theorie (Jovanovic, 1979) verwisselen overgeschoolde werknemers hun baan voor een beter passende zodra het economische klimaat weer aantrekt. Empirisch onderzoek bevestigt dit. Allereerst is een overgeschoolde positie een belangrijke oorzaak van baanontevredenheid (Burris, 1983; Vaisey, 2006), die vervolgens een prikkel is voor individuen op zoek te gaan naar een baan die qua niveau beter aansluit bij hun kennis en vaardigheden (Wolbers, 2003; Gesthuizen \& Dagevos, 2008). Daarnaast is de dynamiek in overscholing hoog: slechts een klein percentage werknemers is langdurig overgekwalificeerd en baanmobiliteit wordt gebruikt om aan overscholing te ontsnappen (Groot \& Maassen van den Brink, 2003). Met andere woorden: overscholing is een tijdelijk probleem, vooral optredend in tijden van hoge werkloosheid, en verdringing onder lager opgeleiden is daarom in hoofdzaak cyclisch van aard. Het beperkte aantal studies in Nederland dat zich richt op cyclische verdringing laat echter een gemengd empirisch beeld zien. Teulings en Koopmanschap (1989) en Van Ours en Ridder (1995) vonden (enige) steun voor cyclische verdringing op de Nederlandse arbeidsmarkt, terwijl Gautier et al. (2002) geen aanwijzingen hiervoor vonden.

\section{Onderzoeksopzet}

De empirische analyse is gebaseerd op gegevens van het OSA Arbeidsaanbodpanel. Deze panelstudie met gedetailleerde informatie over (veranderingen in) de arbeidsmarktpositie van de (potentiële) beroepsbevolking in Nederland is gestart in 1985, met herhaalde metingen die om het jaar plaatsvinden sinds 1986. Tijdens het eerste meetmoment zijn ongeveer 4.000 respondenten uit een representatieve steekproef van ongeveer 2.100 huishoudens ondervraagd. De doelpopulatie bestaat uit huishoudleden in de leeftijd van 16-64 jaar die geen dagonderwijs volgen. Wanneer panelleden uit de eerste meting in latere meetjaren niet meer mee konden of wilden doen, dan zijn zij vervangen door nieuw geselecteerde panelleden en/of huishoudens, die zo veel mogelijk overeenkomen met de oorspronkelijke deelnemers op kenmerken zoals leeftijd, geslacht, gezinsomvang en woonregio. Vanwege beperkingen met betrekking tot de aanwezigheid van relevante variabelen, wordt voor de huidige analyse gebruikgemaakt van de gegevens verkregen in de metingen gehouden in de periode 1988-2004.

Om de dynamiek in overscholing en verdringing op de Nederlandse arbeidsmarkt adequaat te onderzoeken, wordt de overgang van passend werk naar overscholing, werkloosheid of inactiviteit (beide laatste als indicator voor verdringing) en andersom geanalyseerd. ${ }^{2}$ Daartoe zijn de oorspronkelijke (tweejaarlijkse) gegevensbestanden omgezet in een persoon-periode bestand. Omdat periode in relatief grote eenheden is gemeten, namelijk twee jaar, analyseren we overgangskansen met behulp van discrete-tijd gebeurtenissenanalyse. In een dergelijke analyse worden 'hazard rates' gemodelleerd. Een 'hazard rate' geeft de conditionele waar- 
schijnlijkheid weer dat een gebeurtenis, bijvoorbeeld de overgangskans van passend werk naar overscholing, plaatsvindt op tijdstip t, gegeven dat deze gebeurtenis al niet is opgetreden voor tijdstip $t$ (dat wil zeggen, twee jaar daarvoor). Het model kan in algemene zin worden gespecificeerd als een logitmodel, waarbij de 'log odds' (ofwel kansverhouding) van de 'hazard rate' een functie is van een aantal covariaten. Omdat hier meerdere bestemmingen (dat wil zeggen, bij de overgang van passend werk ook werkloosheid en inactiviteit) tegelijkertijd in ogenschouw dienen te worden genomen, wordt een multinomiaal logitmodel geschat, waarbij iedere persoon-periode combinatie als een onafhankelijke waarneming wordt beschouwd (Allison, 1982; Yamaguchi, 1991). De 'risk set' verschilt per afhankelijke variabele. Voor de overgang naar overscholing, werkloosheid of inactiviteit nemen we degenen met passend werk als uitgangspunt. Voor hen is vastgesteld of zij op een gegeven moment de overgang naar een van deze drie bestemmingen maken dan wel passend werk blijven houden. Voor de overgang naar passend werk zijn drie afzonderlijke 'risk sets' gedefinieerd. Een voor degenen die zich in de situatie van overscholing bevinden, een voor degenen die werkloos zijn en een voor hen die inactief zijn. Voor elk van deze drie uitgangssituaties is de overgang naar passend werk de relevante bestemming, waarbij de andere twee mogelijke bestemmingen als 'right censored' worden waargenomen. Overscholing is subjectief gemeten door aan werknemers te vragen of zij hun feitelijke opleidingsniveau als hoger beschouwen dan het niveau dat in hun huidige baan (door de werkgever) is vereist. Is dit het geval, dan is er sprake van overscholing. Anders spreken we van passend werk. Verdringing is vastgesteld door de uiterste consequentie daarvan te bekijken, namelijk of iemand werkloos (en werkzoekend) of inactief (dat wil zeggen, niet-participerend) is. In figuur 1 is per jaar weergegeven 


\section{Figuur 1 De arbeidsmarktpositie van individuen naar jaar}

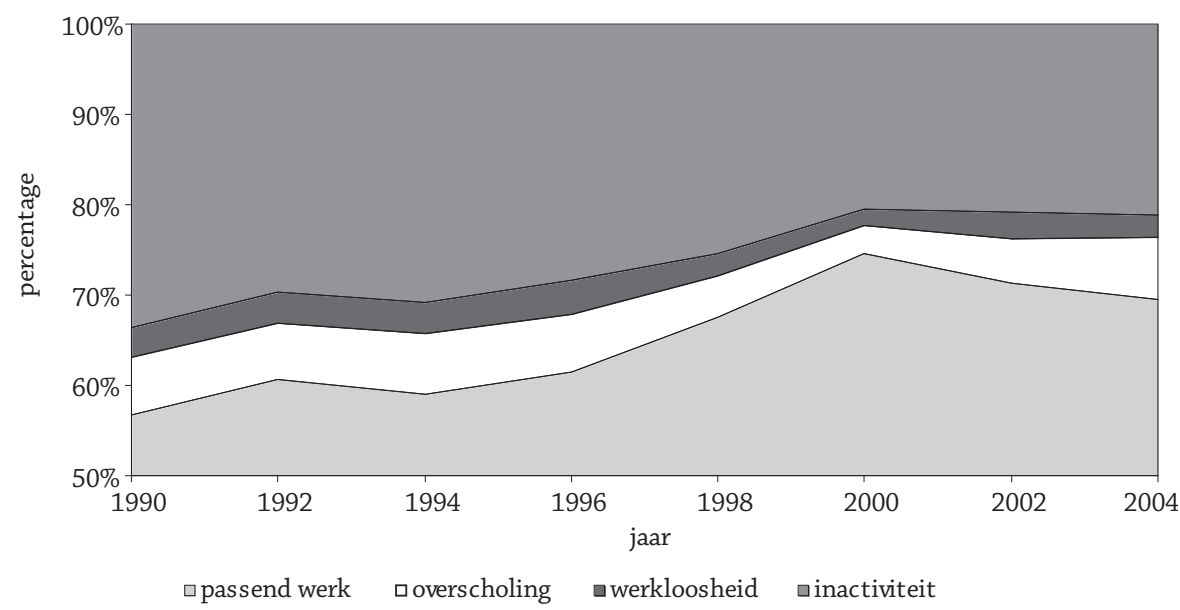

Bron: OSA Arbeidsaanbodpanel 1988-2004

hoe het aantal personen over de vier onderscheiden arbeidsmarktposities is verdeeld.

Verschillende onafhankelijke variabelen zijn in de analyse opgenomen. Periode is gemeten als het jaar waarin een mogelijke overgang op de arbeidsmarkt wordt waargenomen. Hiermee kunnen ontwikkelingen in de dynamiek van overscholing en verdringing op de Nederlandse arbeidsmarkt worden vastgesteld. Vervolgens wordt nagegaan in hoeverre de geobserveerde verschillen tussen jaren kunnen worden toegeschreven aan structurele dan wel cyclische ontwikkelingen op de arbeidmarkt. De indicator voor structurele ontwikkelingen heeft betrekking op de verhouding aanbod/vraag van hoogopgeleiden op de arbeidsmarkt. We meten deze verhouding door het percentage tertiair opgeleiden op de arbeidsmarkt in een bepaald jaar te delen door het percentage hooggeschoold werk in datzelfde jaar. Hoe hoger de ratio is, des te hoger is het aanbod van hoogopgeleiden in verhouding tot de vraag naar hooggeschoold personeel. Cyclische veranderingen operationaliseren we met behulp van jaarlijkse werkloosheidscijfers. Het werkloosheidspeil heeft betrekking op de werkloze beroepsbevolking. De achterliggende cijfers voor beide arbeidsmarktontwikkelingen zijn gebaseerd op informatie van het Centraal Bureau voor de Statistiek (CBS, 2010). In figuur 2 zijn ze grafisch weergegeven. Opleiding is gemeten aan de hand van de volgende vierdeling: primair onderwijs (lo), lager secundair onderwijs (lbo/mavo), hoger secundair onderwijs (havo/vwo/mbo) en tertiair onderwijs (hbo/wo). Het gaat daarbij om het hoogst bereikte opleidingsniveau in het dagonderwijs. Tot slot zijn de variabelen leeftijd en geslacht (vrouw) opgenomen. Met uitzondering van dit laatste kenmerk, zijn alle variabelen tijdsafhankelijk gemeten. 
Figuur 2 Werkloosheidspeil, aanbod hoogopgeleiden, vraag hoogopgeleiden en aanbod/vraag hoogopgeleiden naar jaar

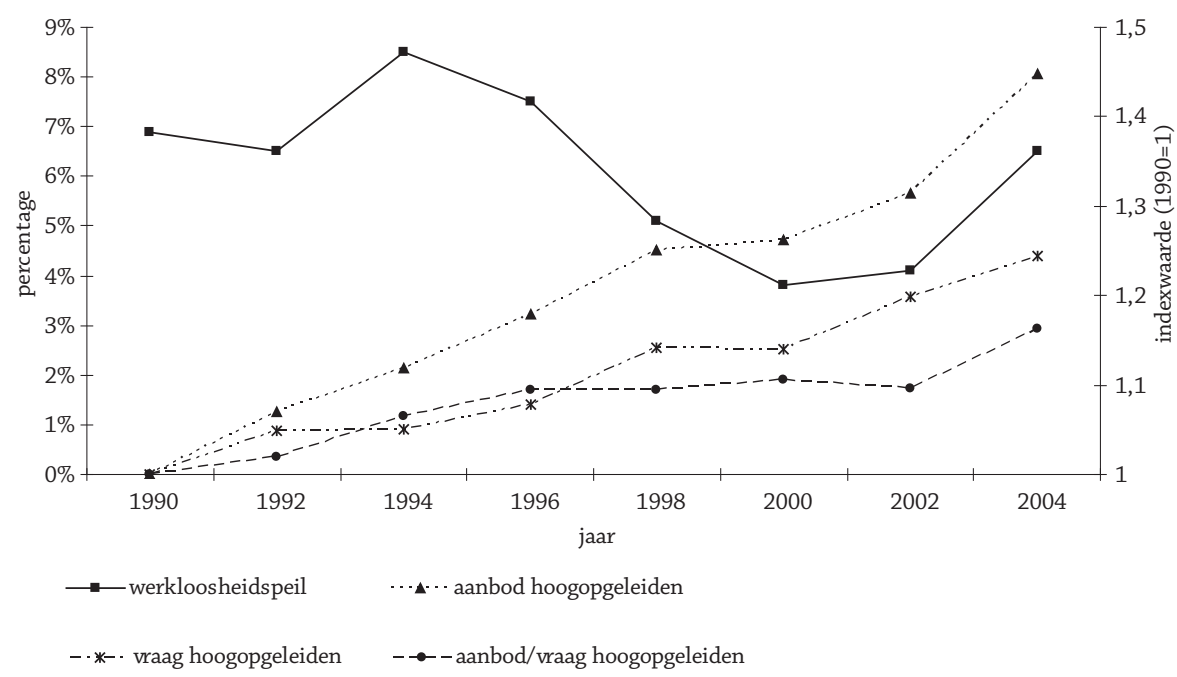

Bron: CBS Statline databank

\section{Resultaten}

In tabel 1 zijn de resultaten van discrete-tijd gebeurtenissenanalyse weergegeven van de overgang van passend werk naar overscholing, werkloosheid of inactiviteit. Model 1 laat zien dat de overgang naar overscholing of werkloosheid het geringst is in het jaar 2000. Zo bedraagt de 'log odds' voor de overgang van passend werk naar overscholing -0,747. Dit houdt in dat de verhouding tussen de kans op overscholing en de kans op passend werk in 2000 ongeveer de helft $\left(\mathrm{e}^{-0,747}=0,474\right)$ is van de overeenkomstige kansverhouding in 1990 , het referentiepunt. Voor de overgang naar inactiviteit geldt dat voor elk onderscheiden jaar de overgangskans significant kleiner is dan voor het jaar 1990. Maar ook hier is het effect het sterkst negatief rond het jaar 2000. Het feit dat de kans op overscholing en verdringing het kleinst is in of rond 2000 pleit als zodanig voor een cyclische interpretatie van deze verschijnselen. Uit figuur 2 is immers al gebleken dat het werkloosheidspeil in dat jaar het laagst was. Een directe toetsing van deze verklaring vindt echter zo meteen plaats in model 2.

Uit model 1 komt verder naar voren dat hoger opgeleiden vaker overgeschoold raken dan lager opgeleiden. Het enige significante verschil is overigens gevonden tussen personen zonder diploma (alleen lo) en degenen met een diploma in het hoger secundair onderwijs (havo/vwo/mbo). De relatieve kansverhouding bedraagt $1,435\left(=\mathrm{e}^{0,361}\right)$. Dit betekent dat - vergeleken met de kans op passend werk - de kans op overscholing voor individuen met een havo/vwo/mbo-diploma bijna anderhalf keer groter is dan de vergelijkbare kans voor individuen zonder diploma. Voor wat betreft de overgang naar werkloosheid of inactiviteit vinden we het tegenovergestelde effect van opleidingsniveau. Het zijn hier vooral de 
lager opgeleiden die werkloos of inactief worden. Deze bevindingen tezamen ondersteunen de verdringingshypothese. Hoger opgeleiden kunnen geen passend werk vinden, accepteren hierdoor een baan onder hun niveau en verdringen daarmee lager opgeleiden direct of indirect (doordat middelbaar opgeleiden de banen van lager opgeleiden gaan bezetten: het cascade-effect) van de arbeidsmarkt.

Ook blijkt uit model 1 dat vrouwen vaker overgeschoold raken dan mannen. Het sekse-effect is nog sterker voor wat betreft de kans op werkloosheid of inactiviteit. ${ }^{3}$ Leeftijd heeft ten slotte een negatief effect op de overgangskans naar overscholing of werkloosheid, maar een positief effect op de overgangskans naar inactiviteit. $^{4}$

In model 2 is het periode-effect vervangen door de twee inhoudelijke invullingen ervan. De resultaten tonen dat het werkloosheidspeil een positieve invloed heeft op alle drie bestemmingen. Hoe hoger de werkloosheid op een bepaald tijdstip is, des te groter is de overgangskans naar overscholing, werkloosheid of inactiviteit. Bij een procent stijging van het werkloosheidspeil neemt de kans op overscholing met 12 procent toe $\left(e^{0,112}=1,119\right)$. Voor de kans op werkloosheid en inactiviteit bedragen deze getallen respectievelijk 21 en 12 procent. Dit zijn duidelijke aanwijzingen dat trends in overscholing en verdringing op de Nederlandse arbeidsmarkt conjunctureel zijn bepaald. Dat de aard van de geconstateerde overscholing en verdringing in Nederland cyclisch is, wordt bovendien bevestigd door het feit dat het overaanbod van hoogopgeleiden (afgemeten aan de hand van ontwikkelingen in het aanbod van hoogopgeleiden gedeeld door de vraag ernaar) geen positieve invloed heeft op de kans op overscholing, werkloosheid of inactiviteit. Voor wat betreft de overgangskans van passend werk naar inactiviteit wordt weliswaar een significante invloed van de ratio tussen het aanbod van en de vraag naar hoogopgeleiden gevonden, maar het geconstateerde effect is tegengesteld aan de verwachte richting.

De analyseresultaten van de overgang in omgekeerde richting (dat wil zeggen, van overscholing, werkloosheid of inactiviteit naar passend werk) zijn weergegeven in tabel 2. Voor wat betreft de trendmatige ontwikkelingen zijn ze het spiegelbeeld van de overgang van passend werk naar overscholing, werkloosheid of inactiviteit. Model 1 toont immers dat de overgangskans naar passend werk, ongeacht de uitgangssituatie, in (en rond) 2000 het grootst is. Ook dit suggereert op voorhand dat de cyclische interpretatie van overscholing en verdringing in Nederland opgeld doet.

Model 1 laat tevens zien dat opleiding alleen een rol speelt bij de overgang van inactiviteit naar passend werk. Hoger opgeleiden hebben een grotere kans om de overgang naar passend werk te maken dan lager opgeleiden. Voor afgestudeerden van het hbo/wo is de kansverhouding op passend werk tegenover inactiviteit tweeënhalf $\left(e^{0,905}=2,472\right)$ keer groter dan de overeenkomstige kansverhouding voor degenen zonder diploma. Verder geldt dat vrouwen minder vaak dan mannen een overgeschoolde positie of een toestand van werkloosheid verlaten en inruilen voor passend werk. Het leeftijdseffect laat ten slotte zien dat oudere werknemers minder snel uit een situatie van verdringing geraken dan jongeren. 
Tabel 1 Resultaten van discrete tijd gebeurtenissenanalyse van de overgang van passend werk naar overscholing, werkloosheid of inactiviteit (logit effecten)

\begin{tabular}{|c|c|c|c|c|c|c|}
\hline \multirow[t]{2}{*}{ Van passend werk naar: } & \multicolumn{2}{|c|}{ Overscholing } & \multicolumn{2}{|c|}{ Werkloosheid } & \multicolumn{2}{|c|}{ Inactiviteit } \\
\hline & Model I & Model 2 & Model I & Model 2 & Model I & Model 2 \\
\hline Intercept & $-2,373 * * *$ & $-4,148 * * *$ & $-3,470 * * *$ & $-5,024 * * *$ & $-6,610 * * *$ & $-2,900 * *$ \\
\hline \multicolumn{7}{|l|}{ Jaar (1990=ref.) } \\
\hline 1992 & $-0,189$ & & 0,076 & & $-0,567^{* * * *}$ & \\
\hline 1994 & $-0,167$ & & $0,525 * *$ & & $-0,420 * * *$ & \\
\hline 1996 & $-0,239$ & & $0,38 \mathrm{I}$ & & $-0,87 \mid * * *$ & \\
\hline 1998 & $-0,653 * * *$ & & $-0,262$ & & $-1,034 * * *$ & \\
\hline 2000 & $-0,747^{* * *}$ & & $-1,156 * * *$ & & $-0,980 * * *$ & \\
\hline 2002 & $-0,293^{*}$ & & 0,237 & & $-1,252 * * *$ & \\
\hline 2004 & 0,078 & & 0,032 & & $-0,902 * * *$ & \\
\hline Werkloosheidspeil & & $0,112 * * *$ & & $0,194 * * *$ & & $0,117 * * *$ \\
\hline Aanbod/vraag hoogopgeleiden & & 0,689 & & 0,292 & & $-4,793 * * *$ \\
\hline \multicolumn{7}{|l|}{ Opleiding ( $L O=$ ref.) } \\
\hline LBO/MAVO & 0,216 & 0,259 & $-0,426 * *$ & $-0,420 *$ & $-0,229 *$ & $-0,200$ \\
\hline HAVO/VWO/MBO & $0,361 * *$ & $0,419 * *$ & $-0,604 * * *$ & $-0,588 * * *$ & $-0,315^{* *}$ & $-0,288 * *$ \\
\hline HBO/WO & 0,266 & $0,358 * *$ & $-0,748 * * *$ & $-0,729 * * *$ & $-0,86 \mid * * *$ & $-0,8 \mid 2^{* * *}$ \\
\hline Vrouw & $0,262 * * *$ & $0,269 * * *$ & $0,838 * * *$ & $0,853^{* * *}$ & $1,024 * * *$ & $1,018 * * *$ \\
\hline Leeftijd & $-0,016 * * *$ & $-0,015^{* *}$ & $-0,013^{*}$ & $-0,011$ & $0,098 * * *$ & $0,097 * * *$ \\
\hline Model $\mathrm{Chi}^{2}$ & $894 * * *$ & $830 * * *$ & $894 * * *$ & $830 * * *$ & $894^{* * *}$ & 830 *** \\
\hline Df & 36 & 21 & 36 & 21 & 36 & 21 \\
\hline Aantal gebeurtenissen & 766 & 766 & 245 & 245 & 681 & 681 \\
\hline Aantal respondenten & 6620 & 6620 & 6620 & 6620 & 6620 & 6620 \\
\hline Aantal sub-episodes & 14818 & 14818 & 14818 & 14818 & 14818 & 14818 \\
\hline
\end{tabular}

Ref. is referentiecategorie; *** $\mathrm{p}<0,01 ; * * \mathrm{p}<0,05 ; * \mathrm{p}<0,10$

Bron: OSA Arbeidsaanbodpanel 1988-2004

De overgangskans van werkloosheid of inactiviteit naar passend werk voor eerstgenoemde groep is immers significant kleiner.

Uit model 2 blijkt dat het werkloosheidspeil een negatief effect heeft op de overgangskans naar passend werk. De invloed is het sterkst bij de overgang van overscholing naar passend werk; het effect is verrassend genoeg niet significant bij de overgang van werkloosheid naar passend werk. Wederom bevestigt dit het beeld dat de waargenomen overscholing en verdringing op de Nederlandse arbeidsmarkt cyclisch van aard is. De ratio tussen het aanbod van en de vraag naar hoogopgeleiden zijn weliswaar significant bij de overgang van werkloosheid naar passend werk, maar het gevonden effect wijst in de tegengestelde richting. 
Tabel 2 Resultaten van discrete tijd gebeurtenissenanalyse van de overgang van overscholing, werkloosheid of inactiviteit naar passend werk (logit effecten)

\begin{tabular}{|c|c|c|c|c|c|c|}
\hline \multirow[t]{2}{*}{ Naar passend werk van: } & \multicolumn{2}{|c|}{ Overscholing } & \multicolumn{2}{|c|}{ Werkloosheid } & \multicolumn{2}{|c|}{ Inactiviteit } \\
\hline & Model I & Model 2 & Model I & Model 2 & Model I & Model 2 \\
\hline Intercept & $1,279 * * *$ & 2,025 & $\mathrm{I}, 889 * * *$ & $-3,190$ & $-0,053$ & 0,007 \\
\hline \multicolumn{7}{|l|}{ Jaar (1990=ref.) } \\
\hline 1992 & 0,028 & & $0,724 * *$ & & $0,269 *$ & \\
\hline 1994 & $-0,409^{*}$ & & 0,439 & & 0,144 & \\
\hline 1996 & $-0,277$ & & $0,615^{* *}$ & & 0,121 & \\
\hline 1998 & $0,479 * *$ & & $0,846 * * *$ & & $0,334^{*}$ & \\
\hline 2000 & $|, 3| 2 * * *$ & & $1,105^{* * * *}$ & & $1,235 * * *$ & \\
\hline 2002 & $0,624^{*}$ & & 0,455 & & $0,870 * * *$ & \\
\hline 2004 & 0,305 & & $1,446 * * *$ & & $0,425 * *$ & \\
\hline Werkloosheidspeil & & $-0,293 * * *$ & & $-0,07 \mid$ & & $-0,199 * * *$ \\
\hline Aanbod/vraag hoogopgeleiden & & 1,165 & & $5,832 * * *$ & & $\mathrm{I}, 420$ \\
\hline \multicolumn{7}{|l|}{ Opleiding ( $L O=r e f)}$. \\
\hline LBO/MAVO & 0,009 & 0,043 & $-0,057$ & $-0,059$ & $0,5 \mid 3 * * *$ & $0,573 * * *$ \\
\hline HAVO/VWO/MBO & $-0,332$ & $-0,299$ & 0,066 & 0,068 & $0,573 * * *$ & $0,634 * * *$ \\
\hline HBO/WO & $-0,428$ & $-0,393$ & 0,098 & 0,089 & $0,852 * * *$ & $0,905^{* * *}$ \\
\hline Vrouw & $-0,420 * * *$ & $-0,4 \mid 5^{* * *}$ & $-0,467 * * *$ & $-0,460 * * *$ & 0,019 & 0,020 \\
\hline Leeftijd & $-0,006$ & $-0,005$ & $-0,056 * * *$ & $-0,058 * * *$ & $-0,078 * * *$ & $-0,077 * * *$ \\
\hline Model $\mathrm{Chi}^{2}$ & $147 * * *$ & $126^{* * * *}$ & $184 * * *$ & $160 * * *$ & $624 * * *$ & $596 * * *$ \\
\hline Df & 36 & 21 & 36 & 21 & 36 & 21 \\
\hline Aantal gebeurtenissen & 906 & 906 & 354 & 354 & 485 & 485 \\
\hline Aantal respondenten & 1109 & 1109 & 722 & 722 & 3036 & 3036 \\
\hline Aantal sub-episodes & 1453 & 1453 & 969 & 969 & 6825 & 6825 \\
\hline
\end{tabular}

Ref. is referentiecategorie; *** $\mathrm{p}<0,01$; ** $\mathrm{p}<0,05 ;{ }^{*} \mathrm{p}<0,10$

Bron: OSA Arbeidsaanbodpanel 1988-2004

\section{Conclusie}

In dit artikel is de dynamiek in overscholing en verdringing op de Nederlandse arbeidsmarkt in de periode 1990-2004 bestudeerd. Daartoe is de overgangkans van passend werk naar overscholing, werkloosheid of inactiviteit (beide laatste als indicator voor verdringing) en andersom geanalyseerd. Meer specifiek is onderzocht of de waargenomen overscholing en verdringing structureel dan wel cyclisch van aard is. Structurele overscholing en verdringing verwijzen naar de ontwikkeling dat de opwaardering van de beroepsarbeid het gestegen opleidingspeil van de beroepsbevolking niet kan bijbenen. Als gevolg daarvan zullen hoger opgeleiden, die niet langer meer de toegang hebben tot de beste posities op de arbeidsmarkt, een baan onder hun niveau accepteren, waardoor ze lager opgelei- 
den verdringen naar nog lagere banen of zelfs naar een positie buiten het actieve arbeidsproces (dat wil zeggen, naar een toestand van werkloosheid of inactiviteit). Overscholing en verdringing zijn daarentegen cyclisch van aard indien beide processen (vooral) optreden als de macro-economische omstandigheden op de arbeidsmarkt ongunstig zijn. Volgens deze gedachtegang accepteren hoger opgeleiden hooguit tijdelijk een baan onder hun niveau (in plaats van werkloos te zijn) en blijven ze zoeken naar passend werk. Zodra de economie weer aantrekt en hoger opgeleiden een passende baan vinden, verdringen zij lager opgeleiden niet langer, waardoor de kansen op werk voor laatstgenoemden toenemen.

De resultaten van de hier uitgevoerde empirische analyse maken duidelijk dat de geobserveerde overscholing en verdringing op de Nederlandse arbeidsmarkt alleen een cyclische oorzaak kennen. Allereerst is aangetoond dat de overgangskans van passend werk naar overscholing, werkloosheid of inactiviteit groter is, naarmate het werkloosheidspeil hoger is. Daarnaast hebben de bevindingen laten zien dat de kans op passend werk vanuit een toestand van overscholing, werkloosheid of inactiviteit kleiner is, wanneer de werkloosheid hoger is. Voor het bestaan van structurele overscholing en verdringing op de Nederlandse arbeidsmarkt zijn geen aanwijzingen gevonden. Deze conclusie gaat in tegen recent ander onderzoek voor Nederland (Gesthuizen \& Wolbers, 2010), maar bevestigt de resultaten van arbeidseconomische studies waarin eerder cyclische overscholing en verdringing werden gevonden (Teulings \& Koopmanschap, 1989; Van Ours \& Ridder, 1995).

Toekomstig onderzoek moet meer licht werpen op deze tegenstrijdige bevindingen. Wellicht maakt de relatief korte onderzoeksperiode in dit artikel (1990-2004), evenals in de arbeidseconomische studies het geval was, het onmogelijk om adequaat structurele van cyclische overscholing en verdringing te onderscheiden. Het is vanuit dit perspectief gezien jammer dat de analyse in 2004 ophoudt. Er is daarna immers veel gebeurd op de Nederlandse arbeidsmarkt. Als de cyclische interpretatie correct is, dan moet de economische recessie van de afgelopen jaren hebben geleid tot een toenemende overscholing en verdringing op de arbeidsmarkt. Beleidsmaatregelen ter voorkoming van (langdurige) werkloosheid en inactiviteit (dat wil zeggen, gesubsidieerde arbeid en bij- of omscholing) zijn dan cruciaal om de arbeidsmarktpositie van met name lager opgeleiden niet verder te laten verslechteren. De keuze van het huidige kabinet om gemeenten flink te korten op hun budget voor re-integratie is in dit opzicht funest.

Nog interessanter is te onderzoeken of de cyclische interpretatie ook standhoudt nu de grote uittocht van de babyboomgeneratie aanstaande is. Door de vergrijzing wordt een structureel tekort aan personeel op de arbeidsmarkt verwacht. Dit zal in algemene zin een dempende werking hebben op de werkloosheid waardoor overscholing en verdringing in de komende periode niet of nauwelijks een probleem mag zijn. Tegelijkertijd echter is het kwalificatieniveau van de (lagere instroom van) nieuwkomers op de arbeidsmarkt een heel stuk hoger dan het opleidingspeil van de (grotere uitstroom van) uittreders waardoor het de vraag is of de kwalitatieve aansluiting tussen onderwijs en arbeidsmarkt in de toekomst voor iedereen wel goed is. Het is mogelijk dat een deel van het beschikbaar komende laaggeschoolde werk, als gevolg van een gebrek aan voldoende lager 
opgeleide schoolverlaters, alsnog door (buitenlandse?) hoger opgeleiden zal worden uitgevoerd. Ofschoon zij daarmee niemand verdringen uit het actieve arbeidsproces, werken zij zelf wel in een baan onder hun niveau. De toekomst zal uitwijzen of dit het geval is.

\section{Noten}

1 Wielers en Glebbeek (1995) beweren dat het stijgende aandeel overgeschoolden in laaggeschoold werk in Nederland niet per se duidt op een toenemende onderbenutting. Ze verschaffen twee aanvullende verklaringen voor deze trend. Allereerst kan het zo zijn dat samen met de opwaardering van de beroepsarbeid in Nederland de taakinhoud van functies is toegenomen, waardoor de formele opleidingsvereisten van functies zijn gestegen. Daarnaast is er empirische steun dat overgeschoolden een hogere arbeidsproductiviteit kennen dan adequaat geschoolden. Het loon van overgeschoolde werknemers ligt weliswaar lager dan dat van gelijk geschoolden in passende banen, maar hoger dan dat van adequaat geschoolden die hetzelfde baanniveau hebben als de overgeschoolden (Hartog \& Oosterbeek, 1988). Het is mogelijk dat alle drie mechanismen werkzaam zijn, maar het is haast onmogelijk ze empirisch van elkaar te scheiden, omdat de centrale concepten (zoals arbeidsproductiviteit) moeilijk te meten zijn.

2 De eerste overgang wordt waargenomen in 1990 met de arbeidsmarktpositie in 1988 als uitgangspunt. Dit betekent dat de periode van observatie betrekking heeft op de jaren 1990-2004.

3 In een eerdere fase zijn de multinomiale logitmodellen ook voor mannen en vrouwen afzonderlijk geschat. Deze bevindingen lieten geen afwijkende patronen zien tussen mannen en vrouwen. Vandaar dat in de getoonde tabellen de resultaten van mannen en vrouwen gezamenlijk zijn gepresenteerd.

4 Eventuele kromlijnigheid in het leeftijdseffect is vastgesteld door een kwadratische term van leeftijd toe te voegen. Deze term bleek in geen van de gevallen significant te zijn, waardoor het effect van leeftijd als een lineair effect wordt geïnterpreteerd.

\section{Literatuur}

Allison, P.D. (1982). Discrete-time methods for the analysis of event histories. Sociological Methodology, 13, 61-98.

Autor, D.A., Katz, L.F. \& Kearney, M.S. (2006). The polarization of the U.S. labor market. American Economic Review Papers and Proceedings, 96, 189-194.

Batenburg, R. \& Witte, M. de (2001). Underemployment in the Netherlands: How the Dutch 'Poldermodel' failed to close the education-jobs gap. Work, Employment \& Society, 15, 73-94.

Becker, G. (1964). Human capital. A theoretical and empirical analysis, with a special reference to education. New York: National Bureau of Economic Research.

Beer, P. de (2006). Perspectieven voor de laagopgeleiden. Tijdschrift voor Arbeidsvraagstukken, 22, 218-233.

Bell, D. (1974). The coming of post-industrial society. London: Heinemann.

Berg, I. (1971). Education and jobs: The great training robbery. Boston, MA: Beacon Press.

Blau, P. \& Duncan, O. (1967). The American occupational structure. New York: Wiley \& Sons. 
Borghans, L. \& Grip, A. de (red.) (2000). The overeducated worker? The economics of skill utilization. Cheltenham, UK/Northampton, USA, MA: Edgar Elgar.

Burris, V. (1983). The social and political consequences of overeducation. American Sociological Review, 48, 454-467.

Burris, V. (2005). Overeducation. Then and now. Work and Occupations, 32, 319-321.

CBS (2010). Statline databank. Voorburg/Heerlen: Centraal Bureau voor de Statistiek. Online beschikbaar via <statline.cbs.nl> (geraadpleegd op 23 februari 2010).

Gautier, P.A., Berg, G.J. van den, Ours, J.C. van \& Ridder, G. (2002). Worker turnover at the firm level and crowding out of lower educated workers. European Economic Review, 46, 523-538.

Gesthuizen, M. (2008). Trends in de arbeidsmarktpositie van laagopgeleiden. Tijdschrift voor Arbeidsvraagstukken, 24, 36-50.

Gesthuizen, M. \& Dagevos, J. (2008). Mismatching of persons and jobs in the Netherlands: Consequences for the returns to mobility. Work, Employment \& Society, 22, 485-506.

Gesthuizen, M. \& Wolbers, M.H.J. (2010). Are low educated men subject to structural or cyclical crowding out? Employment transitions in the Netherlands from 1980 to 2004. Research in Social Stratification and Mobility, 28, 437-451.

Graaf, P.M. de \& Luijkx, R. (1992). Van 'ascription' naar 'achievement'? Trends in statusverwerving in Nederland tussen 1930 en 1980. Mens \& Maatschappij, 67, 412-433.

Groot, W. \& Maassen van den Brink, H. (2003). The dynamics of skill mismatches in the Dutch labor market. In: F. Büchel, A. Mertens \& A. de Grip (red.), Overeducation in Europe: Current issues in theory and policy (pp. 49-64). Cheltenham, UK/Northampton, USA, MA: Edgar Elgar.

Hartog, J. (2000). Overeducation and earnings: Where are we, where should we go? Economics of Education Review, 7, 185-194.

Hartog, J. \& Oosterbeek, H. (1988). Education, allocation and earnings in the Netherlands: Overschooling. Economics of Education Review, 7, 185-194.

Hirsch, F. (1977). Social limits to growth. London: Routledge and Kegan Paul.

Jovanovic, B. (1979). Job matching and the theory of turnover. Journal of Political Economy, 87, 972-990.

Kerr, C., Dunlop, J.T., Harbison, F. \& Myers, C.A. (1960). Industrialism and industrial man. Cambridge, MA: Harvard University Press.

Krueger, A. (1993). How computers have changed the wage structure: evidence from microdata 1984-1989. Quarterly Journal of Economics, 108, 33-60.

Levy, F. \& Murnane, R. (1992). U.S. earnings and earnings inequality: a review of recent trends and proposed explanations. Journal of Economic Literature, 30, 1333-1381.

Livingstone, D.W. (1998). The education-jobs gap. Boulder, CO: Westview Press.

Ours, J.C. van \& Ridder, G. (1995). Job matching and job competition: Are lower educated workers at the back of job queues? European Economic Review, 39, 1717-1731.

Ploeg, S. van der (1994). Educational expansion and returns on credentials. European Sociological Review, 10, 63-78.

Pollmann-Schult, M. (2005). Crowding-out of unskilled workers in the business cycle: Evidence from West Germany. European Sociological Review, 21, 467-480.

Salverda, W., Klaveren, M. van \& Meer, M. van der (red.) (2008). Low-wage work in the Netherlands. New York: Russell Sage Foundation.

Sattinger, M. (1993). Assignment models of the distribution of earnings. Journal of Economic Literature, 31, 851-880.

Spence, M. (1974). Market signaling: Informational transfer in hiring and related screening processes. Cambridge, MA: Harvard University Press. 
Teulings, C. \& Koopmanschap, M. (1989). An econometric model of crowding out of lower educational levels. European Economic Review, 33, 1653-1664.

Thurow, L. (1975). Generating inequality. New York: Basic Books.

Treiman, D. (1970). Industrialization and social stratification. In: E. Laumann (red.), Social stratification, research and theory for the 1970s (pp. 207-234). Indianapolis: BobbsMerill.

Ultee, W.C. (1980). Is education a positional good? An empirical examination of alternative hypotheses on the connection between education and occupational level. The Netherlands' Journal of Sociology, 16, 135-153.

Vaisey, S. (2006). Education and its discontents: Overqualification in America, 1972-2002. Social Forces, 85, 835-864.

Wielers, R. \& Glebbeek, A. (1995). Graduates and the labour market in the Netherlands: three hypotheses and some data. European Journal of Education, 30, 11-30.

Wolbers, M.H.J. (2003). Job mismatches and their labour market effects among schoolleavers in Europe. European Sociological Review, 19, 249-266.

Wolbers, M.H.J. \& Graaf, P.M. de (1996). Langetermijnontwikkelingen in de opbrengsten van diploma's op de Nederlandse arbeidsmarkt. Tijdschrift voor Arbeidsvraagstukken, 12, 296-309.

Wolbers, M.H.J., Graaf, P.M. de \& Ultee, W.C. (2001). Trends in the occupational returns to educational credentials in the Dutch labor market: Changes in structures and in the association? Acta Sociologica, 44, 5-19.

Yamaguchi, K. (1991). Event history analysis. Newbury Park: Sage. 